\title{
Evaluation of cytotoxic, mutagenic and antimutagenic potential of leaf extracts of three medicinal plants using Allium cepa chromosome assay
}

\author{
Selestin Rathnasamy ${ }^{1}$, Kamaruzaman Bin Mohamed ${ }^{1}$, Shaida Fariza Sulaiman ${ }^{1}$, Akeem Akinboro ${ }^{2}$ \\ ${ }^{1}$ School of Biological Sciences, University Science Malaysia, 11800 USM, Penang, Malaysia \\ ${ }^{2}$ Department of Pure and Applied Biology, LAUTECH, Ogbomoso, P.M.B. 4000, Oyo State, Nigeria
}

\begin{abstract}
In the present study, the Allium cepa chromosome assay was employed as a preliminary test to investigate the mutagenic and antimutagenic potential of three plants, namely Clinacanthus nutans, Adhatoda vasica, and Carica papaya, used by traditional practitioners in Malaysia against a direct acting mutagen-Methyl Methanesulphonate (MMS). Onions were planted in various treatment groups: plant extract alone, treatment 1 (pre-treatment with MMS and transfer into plant extracts), and treatment 2 (mixture of MMS and plant extracts). The bulbs planted in the extract alone for cytotoxicity and mutagenicity assessment revealed that none of the extracts of the three plants except the $50 \mathrm{mg} / \mathrm{kg}$ of methanol extract of $A$. vasica were cytotoxic to $A$. cepa cells, but a moderate level of mutagenicity was observed at 200 and $400 \mathrm{mg} / \mathrm{kg}$ of methanol extract of C. papaya and at $400 \mathrm{mg} / \mathrm{kg}$ of aqueous extract of C. nutans. Antimutagenic screening on the other hand revealed that all the extracts tested were able to reduce the percentage chromosomal aberration induced by MMS, both in treatment 1 and 2. Besides that, MMS-induced cell death was also observed to be reduced in onion root cells treated with the plant extracts. Therefore, taking all the results obtained into consideration, the order of the plant extracts with increasing suppressiveness against MMS was C. papaya $<$ A. vasica $<$ C. nutans.
\end{abstract}

Key Words: Allium cepa, Medicinal plants, Cytotoxicity, Mutagenicity, Antimutagenicity.

\section{INTRODUCTION}

It is inevitable that the progress of cancer treatment is not yet effective in reducing worldwide cancer incidence (Jemal et al., 2010; World Health Organization, WHO) and thus new investigations are necessary in reducing the disease occurrence. Cancer is well associated with mutagens that cause oxidative stress in the cells via the production of excessive reactive oxygen species (ROS), the cause of many degenerative diseases including cancer (Halliwell and Getteridge, 1984). This free radical-associated oxidative damage is reducible with ample presence of antioxidants in human body to quench the ROS (Halliwell et al., 1995). Many synthetic antioxidants and drugs were made available in the past few centuries for cancer therapy. However, people are looking forward for remedies that are more nature friendly or in other words, 'drugs of plant origin'. The synthetic drugs are not without side effects (Balasubramaniam et al., 2005) and even many synthetic antioxidants were studied to be toxic and carcinogenic to mammalian cells (Hirose et al., 1998; Kahl, 1984; Safer and Al-Nughamish, 1999).

Fruits, vegetables and plants in general are rich in antioxidants such as flavonoids and phenolic compounds (Luximon-Ramma et al., 2003). These phytochemicals were proven to be effective against various mutagens either through scavenging free radicals or by their reducing power, thus decrease the dangers present by ROS to genome (Akinboro et al., 2011; Mazio and Soliman, 2009). Thus, it is believed that the healing property of phytochemicals was the implicit success of the use of plant based raw materials in the well-known Indian medicinal systems, namely, the Ayurveda, Unani and Siddha and most Chinese folk medicines (Jayaraj, 2010; Kaptchuk, 1947; Krishnaraju et al., 2006).

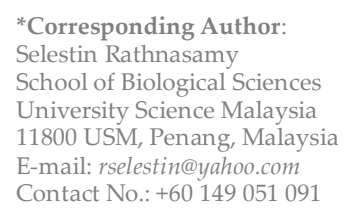

However, it is very important to investigate the pros and cons of the plants to human system. There are many bioassays available to evaluate the cytotoxicity and mutagenicity of various chemical compounds. Among them, higher plants are often used in many studies since they are not expensive, well correlated with other animal test systems, and easily available (Fiskesjö, 1985). Allium cepa, is the common onions introduced by Levan (1938) as an effective test system applicable for toxicity assessment. Some of the interesting features about this plant assay are: the sensitivity to complex mixtures, clear chromosomes $(2 n=16)$, cost effectiveness and availability. Most plants synthesize toxic substances which act as defensive mechanism against insects and herbivores. In addition to that, the poisonous substances may also affect organisms that feed on them including humans. Therefore, it is reasonable that while some medicinal plants may suppress the effects of mutagens, others may have toxic or mutagenic effects (Vicentini et al., 2001). Thus, studies of their mutagenic as well as antimutagenic potential are necessary to establish the safe use of these medicinal plants. This study evaluated aqueous \& methanol extracts of three medicinal plants (Clinacanthus nutans, Adhatoda vasica, and Carica papaya) for mutagenicity and antimutagenicity.

C. nutans, commonly known as Sabah Snake Grass, has been believed to neutralize venomous insect \& snake bites (Wirotesangthong and Rattanakiat, 2006). Apart that, the plant has the potential to treat Herpes Simplex Virus infection, minimize inflammations (Sriwanthana et al., 1996; Wirotesangthong and Rattanakiat, 2006), \& to reduce in vitro carcinogenic effects (Yong et al., 2013). A. vasica, also known as Malabar Nut Tree is part of Acanthaceae plant family which is used widely among Indians for the treatment of inflammation (Chakraborty \& Brantner, 2001), cold, cough, chronic bronchitis (Amin \& Mehta, 1959), cataract (Patel et al., 2012), asthma, piles, glandular tumor \& to cure fresh wounds (Ayyanar and Ignacimuthu, 2008; Dhuley, 1999; Palasuwan et al., 2005). The pharmacological activities may be due to the presence of vasicine, vasicinone and vasicinol, which are the major alkaloids found in A. vasica (Padmaja et al., 2011). 
Carica papaya (papaya) belongs to the family Caricaceae, native to all tropical countries. The plant is well known for its fruits \& its parts are used for microbial infections (Sharmeen et al., 2012), treating burns \& wounds, fever, intestinal nematode infection, asthma, \& gastric (Runnie et al., 2004; starleyet al., 1999; Stepek et al., 2004). Moreover, according to Mazzio \& Soliman (2009), the extract of papaya leave showed antitumor activity when tested in Neuro-2A cell lines.

The aim of this study was to evaluate the cytotoxic, mutagenic and antimutagenic potentials of aqueous and methanol leaf extracts of $C$. nutans, $A$. vasica \& C. papaya with a view to determine their effectiveness in suppressing and/or repairing the damages caused by Methyl methanesulphonate (MMS), a potential cancer causing agent, in cells in vivo.

\section{MATERIALS AND METHODS}

\section{Reagents}

Methanol, Acetic Acid, Ethanol, Hydrochloric Acid ( $\mathrm{HCl})$, Orcein(for staining), and Methyl methanesulfonate (MMS) were purchased from Sigma and Aldrich.

\section{Plant materials}

C. nutans leaves were purchased from a farmer at Balik Pulau, Penang, Malaysia. A. vasica and C. papaya leaves were obtained from a local farm in Kedah, Malaysia. The plants were identified by expert, Dr. Shaida Fariza Sulaiman and voucher specimens of C. nutans, A. vasica, and $C$. papaya were deposited at the herbarium of University Science Malaysia (11351, 11352, and 11353, respectively). The plants were thoroughly cleaned under running tap water and left at room temperature for few hours before transferring into a dryer and dried at $40^{\circ} \mathrm{C}$ until they were completely dried. Well dried leaves were then powdered and kept in air-tight bottles. Distilled water and methanol were used as inorganic and organic solvents respectively for the preparation of extracts. Aqueous extract was prepared by dissolving the plant powders in distilled water and placed in water bath at $40^{\circ} \mathrm{C}$ and constantly shook using a shaker fixed to the water bath. Methanol extract was prepared using rotary shaker at 200rpm. The extracts was then obtained after 24hrs and concentrated in a dryer at $40^{\circ} \mathrm{C}$ (Nair and Chanda, 2007). Concentrated gummy plant extracts were freeze-dried and kept refrigerated until use.

\section{Macroscopic analysis}

The Allium cepa assay used in this study was with few modifications of the previously reported method (Fiskesjö, 1985). Onion bulbs of same size were purchased from a local market and sun dried for three days until the outer scales were easily removable. During the de-scaling process, the older roots from the primordial root ring were carefully removed without harming the root ring. The bulbs were then thoroughly rinsed under running tap water to remove traces of herbicides and chemicals if any. Thereafter, bulbs were suspended in tap water (negative control) and different concentrations (500, 1000, 1500, $2000 \mathrm{mg} / \mathrm{kg}$ ) of extracts dissolved in $50 \mathrm{~mL}$ of tap water. An EC50 (effective concentration at 50\% inhibition of root growth) curve was plotted using the data collected.

\section{Microscopic analysis}

Mutagenic evaluation was performed by suspending the onion bulbs in different concentrations of aqueous and methanol extracts and left for $48 \mathrm{hrs}$. As for antimutagenic evaluation, $50 \mu \mathrm{l} / \mathrm{kg}$ of Methyl methanesulfonate (MMS) was used for positive control. The Bulbs were processed and tested in two different treatments. In the first treatment (treatment 1) of the Allium test, bulbs were allowed to produce roots in MMS alone for $24 \mathrm{hrs}$ and then transferred into different concentrations of the extracts and left for another 24hrs. In the second treatment (treatment 2), bulbs were planted in a mixture of different concentrations of the extracts and MMS. The growth media was renewed after every $24 \mathrm{hrs}$.

The first treatment was designed in order to know the ability of plant extracts to repair the damages caused by the mutagen to cells. On the other hand, second treatment was planned to observe the suppressive effect of plant extracts against MMS in the cells of A. cepa. Allium roots were collected after $48 \mathrm{hrs}$ and fixed in a solution of three to one ratio of ethanol/ acetic acid. For the slide preparation, $1 \mathrm{~N} \mathrm{HCl}$ and Aceto-orcein were used for hydrolysis and staining the root cells respectively. On each slide, normal and abnormal/aberrant dividing cells among a total of 1000 cells were scored and recorded in a tally manner. The data were pooled together for statistical analysis of Mitotic Index (MI), the frequency of chromosomal aberration (CA) as well as the percentage reduction of MMS-induced CA. The calculations followed the previous studies (Akinboro et al., 2011; Fiskesjö, 1985).

$\mathrm{MI}=\frac{\mathrm{A}}{\mathrm{B}} \times 100 \%$

MI: mitotic index, A: total dividing cells, B: Total counted cells per concentration

$\mathrm{CA}=\frac{\mathrm{C}}{\mathrm{B}} \times 100 \%$

CA: frequency of chromosomal aberration, $\mathrm{C}$ : total aberrant cells, B: Total counted cells

$\mathrm{RCA}=\frac{\mathrm{a}-\mathrm{b}}{\mathrm{a}-\mathrm{c}} \times 100 \%$

RCA: percentage reduction of MMS-induced chromosomal aberration, a: percentage of MMS-induced CA, b: percentage of plant extracts and MMS-induced CA, c: percentage of tap water-induced CA.

\section{Statistical analysis}

The 'IBM SPSS 20 ' package was used to analyse the data. The means, with $95 \%$ confidence limit and the standard errors of each of the data obtained were calculated. The significant difference between control groups and samples was set at $\mathrm{p} \leq 0.05$.

\section{RESULTS}

Table 1 represents the effects of aqueous and methanol extracts of Clinacanthus nutans, Adhatoda vasica, and Carica papaya on root growth of Allium cepa. As expected, negative control (tap water) gave the highest root growth compared to plant extracts. The root growth inhibition was concentration dependent. Among all the tested concentrations, root growth was highest in $500 \mathrm{mg} / \mathrm{kg}$ while it was lowest in $2000 \mathrm{mg} / \mathrm{kg}$. The EC 50 values of the aqueous extracts of $C$. nutans, $A$. vasica, and $C$. papaya were 630, 420, and $355 \mathrm{mg} / \mathrm{kg}$, respectively. Comparatively, methanol extracts of C. nutans, A. vasica, and C. papaya were found to promote $50 \%$ root growth (compared to control) of onions at 800,460 , and $360 \mathrm{mg} / \mathrm{kg}$, respectively. The mitotic index (MI) and chromosomal aberration (CA) in Allium cepa root cells induced by the plant extracts were also evaluated. The MI values obtained for all treatments were shown in Figure $1(1 \mathrm{a}, 1 \mathrm{~b}, 1 \mathrm{c})$. As for the treatment with plant extracts alone, the MI values of control group 
Table 1: Effects of plant extracts on Allium cepa root growth.

\begin{tabular}{|c|c|c|c|c|c|c|c|c|c|c|c|c|}
\hline \multirow{3}{*}{$\begin{array}{l}\text { Conc. } \\
(\mathrm{mg} / \mathrm{kg})\end{array}$} & \multicolumn{4}{|c|}{ Clinacanthus nutans } & \multicolumn{4}{|c|}{ Adhatoda vasica } & \multicolumn{4}{|c|}{ Carica papaya } \\
\hline & \multicolumn{2}{|c|}{ Aqueous } & \multicolumn{2}{|c|}{ Methanol } & \multicolumn{2}{|c|}{ Aqueous } & \multicolumn{2}{|c|}{ Methanol } & \multicolumn{2}{|c|}{ Aqueous } & \multicolumn{2}{|c|}{ Methanol } \\
\hline & Mean RL \pm SE & $\%$ RG & Mean RL \pm SE & $\%$ RG & Mean RL \pm SE & $\%$ RG & Mean RL \pm SE & $\%$ RG & Mean RL \pm SE & $\%$ RG & Mean RL \pm SE & $\%$ RG \\
\hline $\mathrm{NC}$ & $1.9 \pm 0.25$ & - & $1.5 \pm 0.36$ & - & $3.6 \pm 0.30$ & - & $3.2 \pm 0.21$ & - & $3.6 \pm 0.43$ & - & $3.9 \pm 0.21$ & - \\
\hline 500 & $1.1 \pm 0.13$ & 60.00 & $1.3 \pm 0.12$ & 69.00 & $1.4 \pm 0.16$ & 40.28 & $1.4 \pm 0.09$ & 44.94 & $1.0 \pm 0.16$ & 29.01 & $1.1 \pm 0.17$ & 29.35 \\
\hline 1000 & $0.4 \pm 0.06$ & 20.54 & $0.6 \pm 0.11$ & 30.81 & $1.2 \pm 0.18$ & 32.39 & $0.9 \pm 0.14$ & 29.11 & $0.7 \pm 0.16$ & 20.28 & $0.5 \pm 0.07$ & 12.99 \\
\hline 1500 & $0.4 \pm 0.12$ & 23.51 & $0.8 \pm 0.07$ & 42.02 & $1.0 \pm 0.09$ & 29.01 & $0.9 \pm 0.17$ & 29.43 & $0.5 \pm 0.15$ & 13.24 & $0.4 \pm 0.06$ & 10.13 \\
\hline 2000 & $0.5 \pm 0.07$ & 25.95 & 0.700 & 37.84 & $0.8 \pm 0.08$ & 21.13 & $0.8 \pm 0.10$ & 23.73 & $0.5 \pm 0.14$ & 14.08 & $0.5 \pm 0.03$ & 12.47 \\
\hline EC50 & \multicolumn{2}{|c|}{$630 \mathrm{mg} / \mathrm{kg}$} & \multicolumn{2}{|c|}{$800 \mathrm{mg} / \mathrm{kg}$} & \multicolumn{2}{|c|}{$420 \mathrm{mg} / \mathrm{kg}$} & \multicolumn{2}{|c|}{$460 \mathrm{mg} / \mathrm{kg}$} & \multicolumn{2}{|c|}{$355 \mathrm{mg} / \mathrm{kg}$} & \multicolumn{2}{|c|}{$360 \mathrm{mg} / \mathrm{kg}$} \\
\hline
\end{tabular}

Mean RL: mean root length, \% RG: \% of root growth in treatment as compared to control, S.E: standard error

Table 2.1: Chromosomal aberrations observed in Allium cepa root cells treated with aqueous extracts alone.

\begin{tabular}{|c|c|c|c|c|c|c|c|c|c|c|c|}
\hline \multirow{2}{*}{$\begin{array}{l}\text { Aqueous } \\
\text { extracts }\end{array}$} & \multirow{2}{*}{$\begin{array}{l}\text { Conc. } \\
\text { (mg/kg) }\end{array}$} & \multicolumn{9}{|c|}{ Chromosomal aberrations (CA) } & \multirow[b]{2}{*}{$\begin{array}{c}\text { Freq. of Cell } \\
\text { death }\end{array}$} \\
\hline & & Bridges & $\begin{array}{l}\text { Disturbed } \\
\text { spindle }\end{array}$ & Polyploidy & Laggards & $\begin{array}{c}\text { Lost } \\
\text { fragments }\end{array}$ & $\begin{array}{l}\text { Vagrant } \\
\text { chrom. }\end{array}$ & $\begin{array}{l}\text { Sticky } \\
\text { chrom. }\end{array}$ & Others & $\begin{array}{c}\text { Freq. of CA } \\
(\%)\end{array}$ & \\
\hline \multirow{5}{*}{ C. nutans } & $\mathrm{NC}$ & 1 & 2 & - & - & - & - & 3 & - & 0.14 & 0.18 \\
\hline & 100 & 3 & 1 & - & - & - & - & 6 & - & 0.20 & 0.24 \\
\hline & 200 & 2 & 4 & - & - & 1 & - & 5 & - & 0.24 & 0.16 \\
\hline & 400 & 8 & 7 & 1 & 4 & - & - & 7 & - & $0.54^{*}$ & 0.42 \\
\hline & 800 & 5 & 4 & - & - & - & 1 & 6 & 1 & 0.34 & 0.56 \\
\hline \multirow{5}{*}{ A. vasica } & NC & 3 & 1 & - & - & - & - & 4 & - & 0.16 & 0.20 \\
\hline & 50 & 2 & 2 & - & - & 1 & - & 4 & - & 0.18 & 0.24 \\
\hline & 100 & 2 & 1 & - & - & - & - & 6 & - & 0.18 & 0.20 \\
\hline & 200 & 4 & 1 & - & - & 1 & - & 1 & - & 0.14 & 0.32 \\
\hline & 400 & 5 & 4 & - & - & - & - & 7 & - & 0.32 & $1.02^{*}$ \\
\hline \multirow{5}{*}{ C. papaya } & $\mathrm{NC}$ & - & 3 & - & - & - & - & 1 & - & 0.08 & 0.16 \\
\hline & 50 & - & 2 & - & - & - & - & 3 & 1 & 0.12 & 0.46 \\
\hline & 100 & 1 & 1 & - & - & 1 & - & 1 & - & 0.08 & 0.08 \\
\hline & 200 & 2 & - & - & - & - & - & 2 & - & 0.08 & 0.12 \\
\hline & 400 & 2 & - & - & - & - & - & 4 & - & 0.08 & 0.32 \\
\hline
\end{tabular}

NC: negative control. Conc.: concentration. ${ }^{*} \mathrm{p} \leq 0.05$ values are significantly higher than negative control.

Table 2.2: Chromosomal aberrations observed in Allium cepa root cells treated with methanol extracts alone.

\begin{tabular}{|c|c|c|c|c|c|c|c|c|c|c|c|}
\hline \multirow{2}{*}{$\begin{array}{l}\text { Methanol } \\
\text { extracts }\end{array}$} & \multirow{2}{*}{$\begin{array}{l}\text { Conc. } \\
\text { (mg/kg) }\end{array}$} & \multicolumn{9}{|c|}{ Chromosomal aberrations (CA) } & \multirow[b]{2}{*}{$\begin{array}{c}\text { Freq. of Cell } \\
\text { death }\end{array}$} \\
\hline & & Bridges & $\begin{array}{l}\text { Disturbed } \\
\text { spindle }\end{array}$ & Polyploidy & Laggards & $\begin{array}{c}\text { Lost } \\
\text { fragments }\end{array}$ & $\begin{array}{l}\text { Vagrant } \\
\text { chrom. }\end{array}$ & $\begin{array}{l}\text { Sticky } \\
\text { chrom. }\end{array}$ & Others & $\begin{array}{c}\text { Freq. of CA } \\
(\%)\end{array}$ & \\
\hline \multirow{5}{*}{ C. nutans } & $\mathrm{NC}$ & 3 & 4 & - & - & - & 2 & 8 & - & 0.34 & 0.16 \\
\hline & 100 & 5 & 3 & - & - & - & - & 6 & 4 & 0.36 & 0.16 \\
\hline & 200 & 6 & 2 & 1 & - & - & - & 9 & 1 & 0.38 & 0.18 \\
\hline & 400 & 3 & 1 & - & - & - & - & 7 & 1 & 0.26 & $0.86^{*}$ \\
\hline & 800 & - & - & - & - & - & - & 3 & - & 0.06 & 0.64 \\
\hline \multirow{5}{*}{ A. vasica } & $\mathrm{NC}$ & 3 & 1 & - & - & - & - & 2 & - & 0.12 & 0.18 \\
\hline & 50 & 1 & - & - & - & 1 & - & - & - & 0.04 & 0.62 \\
\hline & 100 & 2 & 1 & - & - & 1 & - & 1 & - & 0.10 & $1.26^{*}$ \\
\hline & 200 & 1 & - & - & - & 1 & - & 6 & 3 & 0.22 & 0.88 \\
\hline & 400 & 3 & 1 & - & - & - & - & 3 & 1 & 0.16 & $1.44^{*}$ \\
\hline \multirow{5}{*}{ C. papaya } & $\mathrm{NC}$ & 2 & - & - & - & - & - & 1 & - & 0.06 & 0.14 \\
\hline & 50 & 6 & 1 & - & - & - & - & 4 & - & 0.22 & $0.98^{*}$ \\
\hline & 100 & 4 & 1 & - & 4 & - & - & 4 & 1 & 0.28 & $2.44^{*}$ \\
\hline & 200 & 5 & 1 & - & 1 & - & - & 7 & 1 & $0.30^{*}$ & $1.76^{*}$ \\
\hline & 400 & 6 & 1 & - & - & - & - & 6 & 3 & $0.34^{*}$ & $1.32^{*}$ \\
\hline
\end{tabular}

NC: negative control. Conc.: concentration. ${ }^{*} \mathrm{p} \leq 0.05$ values are significantly higher than negative control.

were found to be higher compared to the aqueous and methanol extracts of $C$. nutans and A. vasica, respectively. However, the rest of the plant extracts at certain concentrations showed better mitotic cell division compared to negative control. Although there were differences in MI as stated earlier, the values were not significantly varies from control group, except at $50 \mathrm{mg} / \mathrm{kg}$ of methanol extract of $A$. vasica. The mitotic index value obtained for all plant extracts in the presence of MMS, whether cotreated or pre-treated, were reduced to the extent where the values were significantly lower than negative control, except at all the concentrations and at 100 and $200 \mathrm{mg} / \mathrm{kg}$ of aqueous and methanol extracts of $C$. nutans respectively and $200 \mathrm{mg} / \mathrm{kg}$ of aqueous extract of $A$. vasica.
CAs induced by plant extracts alone and in mixture of extracts and MMS (in treatment 1 and 2) were detailed in tables 2 and 3. Significant differences in frequency of $\mathrm{CA}$ among negative control and extracts alone were noted only at $400 \mathrm{mg} / \mathrm{kg}$ of aqueous extract of C. nutans and at 200 and $400 \mathrm{mg} / \mathrm{kg}$ of methanol extract of C. papaya. As for mixture of the plant extract and MMS, CA was expressed as percentage among total number of dividing cells for easy calculation of percentage reduction of CA induced by MMS. The percentages of CAs induced by MMS in each treatment were found to be higher than that observed in the negative control. On the other hand, all the plant extracts, at all the tested concentrations, were highly capable to reduce the percentage of CA-induced by MMS in A. cepa root cells. 


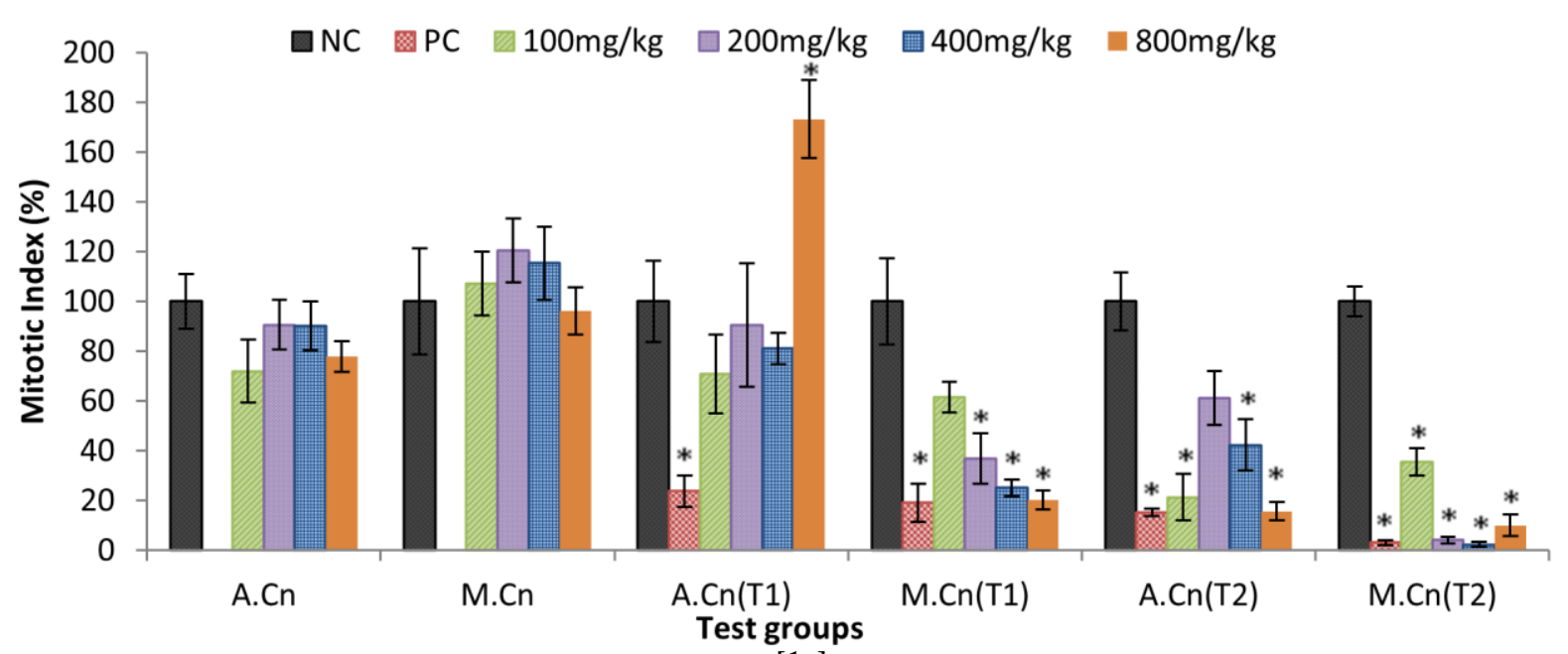

[1a]

$\square \mathrm{NC} \quad \mathrm{PC} \square 50 \mathrm{mg} / \mathrm{kg} \square 100 \mathrm{mg} / \mathrm{kg} \square 200 \mathrm{mg} / \mathrm{kg} \quad \square 00 \mathrm{mg} / \mathrm{kg}$

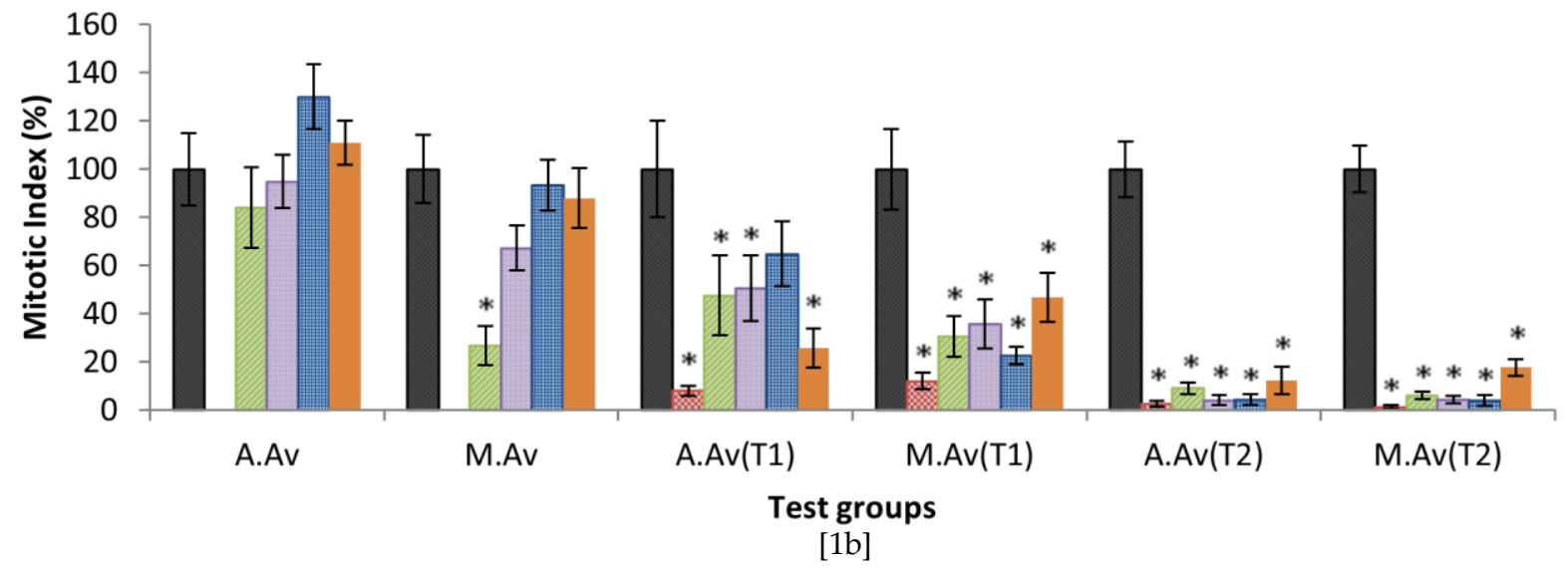

$\square \mathrm{NC} \quad \mathrm{PC} \square 50 \mathrm{mg} / \mathrm{kg} \quad \square 100 \mathrm{mg} / \mathrm{kg} \square 200 \mathrm{mg} / \mathrm{kg} \quad \square 00 \mathrm{mg} / \mathrm{kg}$

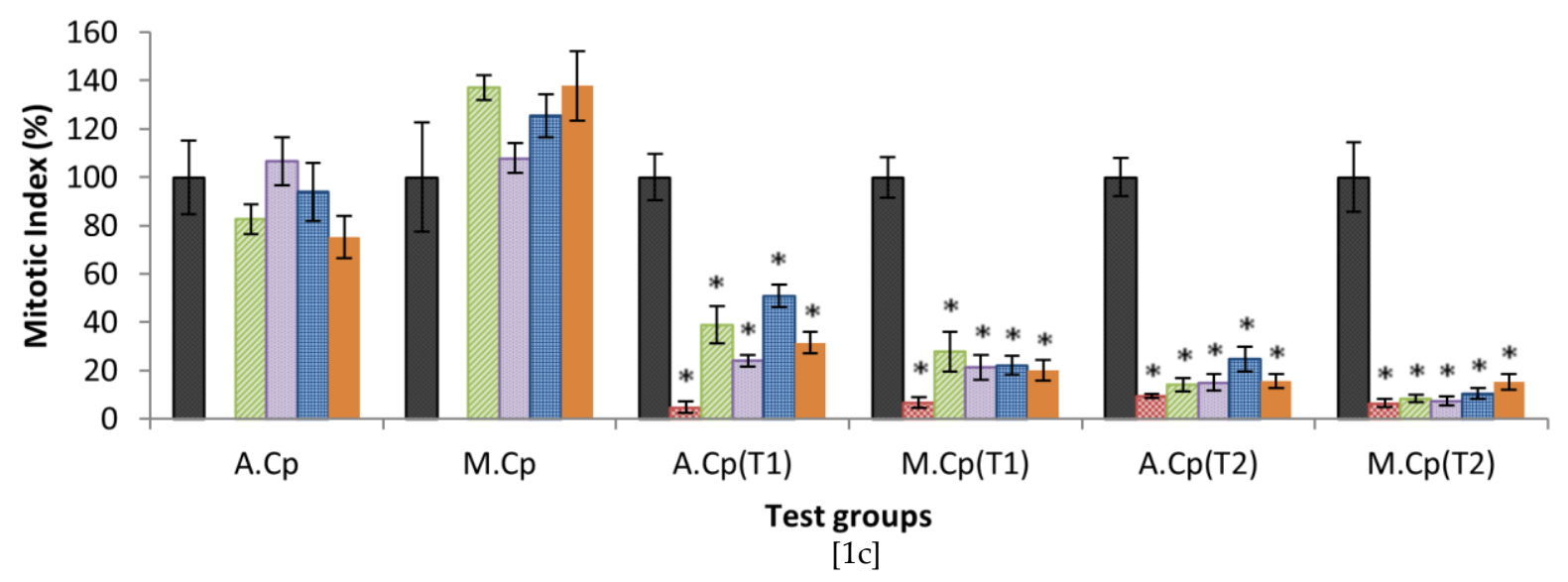

Figure $1(\mathrm{a}, \mathrm{b}, \mathrm{c})$ : percentage mitotic cell division of $C$. nutans, $A$. vasica, $C$. papaya extracts obtained for extracts alone, treatment 1 (T1), and treatment 2 (T2). A: aqueous, M: methanol, Cn: C. nutans, Av: A. vasica, Cp: C. papaya.

${ }^{*}$ values are significantly different than negative control $(\mathrm{p} \leq 0.05)$. 


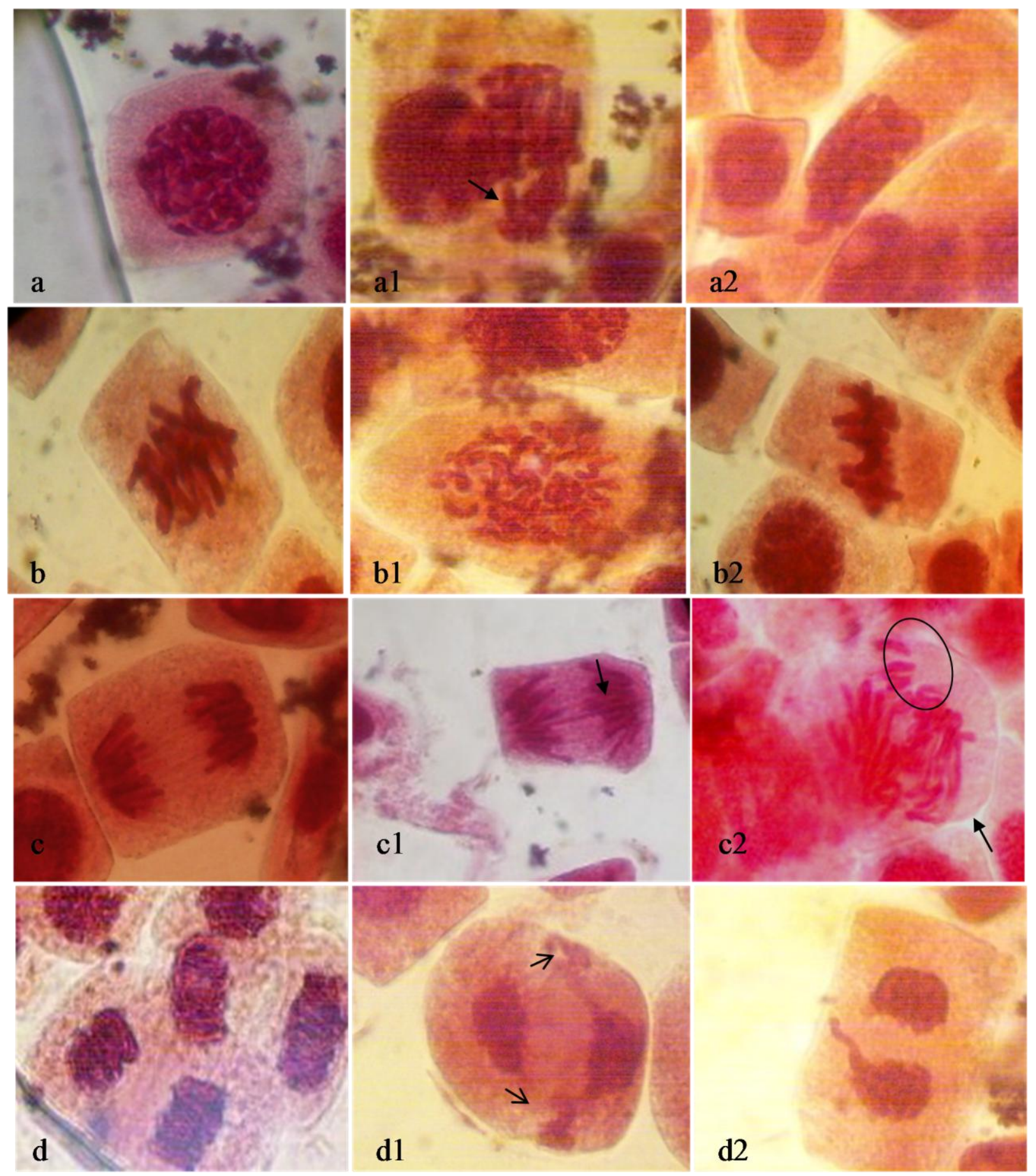

Figure 2: Dividing cells of $A$.cepa treated with plant extracts, controls and mixture of extracts and MMS. Normal prophase, metaphase, anaphase, and telophase were represented by (a), (b), (c) and (d), respectively. (a1) disturbed spindle in prophase (a2) sticky prophase (b1) c-metaphase (b2) sticky metaphase (c1) bridge (c2) chromosome lag and disturbed spindle (d1) vagrant chromosome (d2) laggard. (Magnification=100x) 

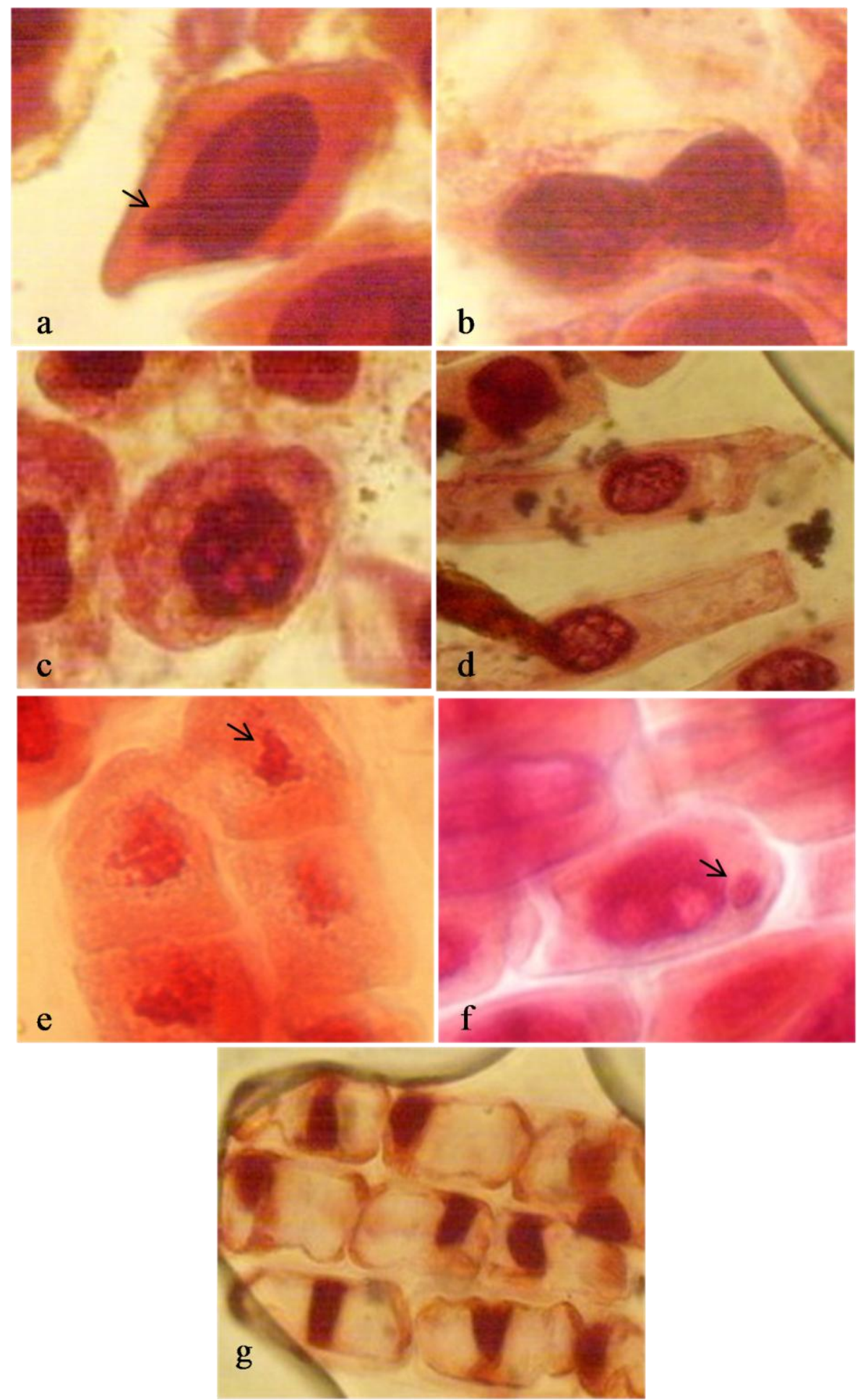

Figure 3: Cells with morphological impairment and in death phase. (a) Cell with nuclear bud (b) Interphasic nucleus with interconnected bridge (c) Cytoplasmic vacuolization (d) Deformed nucleus (e) Fragmented nucleus (f) Micronucleus (g) Condensed nucleus/cells with enlarged cytoplasmic volume. (Magnification=100x). 
Table 3.1: Antimutagenic effect of plant extracts on MMS-induced CA (Treatment 1) in A. cepa root cells.

\begin{tabular}{|c|c|c|c|c|c|c|}
\hline Plant extract & $\begin{array}{l}\text { Conc. } \\
\text { (mg/kg) }\end{array}$ & $\begin{array}{l}\text { Total dividing } \\
\text { cells }\end{array}$ & $\begin{array}{c}\text { Total aberrant } \\
\text { cells }\end{array}$ & $\begin{array}{l}\% \text { CA in total } \\
\text { dividing cells }\end{array}$ & $\begin{array}{l}\text { \% reduction } \\
\text { of } C A\end{array}$ & $\begin{array}{l}\text { Cell } \\
\text { death }\end{array}$ \\
\hline \multirow{6}{*}{$\begin{array}{l}\text { Aqueous extract of } \\
\text { C. nutans }\end{array}$} & $\mathrm{NC}$ & 433 & 9 & 2.08 & - & 0.40 \\
\hline & MMS & 103 & 11 & $10.68^{*}$ & - & 1.26 \\
\hline & 100 & 307 & 5 & 1.63 & 105.23 & 0.50 \\
\hline & 200 & 392 & 15 & 3.83 & 79.65 & 0.40 \\
\hline & 400 & 351 & 11 & 3.13 & 87.79 & 0.38 \\
\hline & 800 & 750 & 46 & 6.13 & 52.91 & 0.06 \\
\hline \multirow{6}{*}{$\begin{array}{l}\text { Methanol extract of } \\
\text { C. nutans }\end{array}$} & $\mathrm{NC}$ & 483 & 8 & 1.66 & - & 0.26 \\
\hline & MMS & 92 & 13 & $14.13^{*}$ & - & $6.56^{*}$ \\
\hline & 100 & 297 & 7 & 2.36 & 94.37 & $1.32^{*}$ \\
\hline & 200 & 178 & 6 & 3.37 & 86.29 & $1.96^{*}$ \\
\hline & 400 & 121 & 8 & 6.61 & 60.30 & 1.10 \\
\hline & 800 & 98 & 4 & 4.08 & 80.59 & 0.52 \\
\hline \multirow{6}{*}{$\begin{array}{l}\text { Aqueous extract of } \\
\text { A. vasica }\end{array}$} & $\mathrm{NC}$ & 398 & 10 & 2.51 & - & 0.22 \\
\hline & MMS & 32 & 7 & $21.88^{*}$ & - & $8.36^{*}$ \\
\hline & 50 & 189 & 10 & 5.29 & 85.65 & $1.64^{*}$ \\
\hline & 100 & 201 & 6 & 2.99 & 97.52 & $2.02^{*}$ \\
\hline & 200 & 258 & 13 & 5.04 & 86.94 & 0.86 \\
\hline & 400 & 102 & 1 & 0.98 & 107.89 & 0.54 \\
\hline \multirow{6}{*}{$\begin{array}{c}\text { Methanol extract of } \\
\text { A. vasica }\end{array}$} & $\mathrm{NC}$ & 433 & 2 & 0.46 & - & 0.04 \\
\hline & MMS & 52 & 11 & $21.15^{*}$ & - & $6.20^{*}$ \\
\hline & 50 & 132 & 3 & 2.27 & 91.25 & $1.08^{*}$ \\
\hline & 100 & 155 & 7 & 4.52 & 80.38 & 0.96 \\
\hline & 200 & 98 & 1 & 1.02 & 97.29 & 0.78 \\
\hline & 400 & 202 & 2 & 0.99 & 97.44 & 0.44 \\
\hline \multirow{6}{*}{$\begin{array}{l}\text { Aqueous extract of } \\
\text { C. papaya }\end{array}$} & $\mathrm{NC}$ & 573 & 10 & 1.75 & - & 0.34 \\
\hline & MMS & 27 & 6 & $22.22^{*}$ & - & $5.66^{*}$ \\
\hline & 50 & 223 & 7 & 3.14 & 93.21 & 1.38 \\
\hline & 100 & 138 & 6 & 4.34 & 87.35 & 3.48 \\
\hline & 200 & 291 & 8 & 2.75 & 95.11 & 1.40 \\
\hline & 400 & 179 & 2 & 1.12 & 103.08 & 0.50 \\
\hline \multirow{6}{*}{$\begin{array}{l}\text { Methanol extract of } \\
\text { C. papaya }\end{array}$} & $\mathrm{NC}$ & 435 & 11 & 2.53 & - & 0.34 \\
\hline & MMS & 29 & 6 & $20.69^{*}$ & - & $3.76^{*}$ \\
\hline & 50 & 121 & 8 & 6.61 & 77.53 & 0.30 \\
\hline & 100 & 93 & 5 & 5.38 & 84.31 & 0.86 \\
\hline & 200 & 96 & 7 & 7.29 & 73.79 & 0.80 \\
\hline & 400 & 88 & 2 & 2.27 & 101.43 & 0.50 \\
\hline
\end{tabular}

Conc.: concentration * indicates significant difference from negative control (NC), $\mathrm{p} \leq 0.05$.

Some pictures of the normal and abnormal dividing cells were shown in Figure 2. During microscopic evaluation, cells with distorted morphologies were also found. The numbers of cells in death phase (CD) were calculated as percentage among total cells observed per concentration. CDs were noted to be higher in all the meristematic cells of A. cepa treated with MMS alone. Besides that, statistically significant differences from the CDs of negative control were also noted at several concentrations of all the plant extracts, though their potential to reduce the MMSinduced cell death was convenient. Various cellular morphological abnormalities were illustrated in Figure 3.

\section{DISCUSSION}

Generally, plants would produce hazardous secondary metabolites which might be used as their defensive mechanisms. Following that, several reports have indicated the toxicity of some plants used in traditional medicines if consumed above certain concentrations, though their potentials to cure diseases were also mentioned (Razak et al., 2007; Valerio and Gonzales, 2005: Wanyoike et al., 2004). Therefore, despite the study about the efficacy and mechanisms of plants to cure diseases, it is also vital to study the potential dangers they might present. As per above concern, mutagenicity as well as antimutagenicity of leave extracts of C. nutans, A. vasica, and $C$. papaya were evaluated using the $A$. cepa chromosome assay. Based on the range finding test, $\mathrm{EC}_{50}$ in order of increasing root growth inhibitory effect of the three plant extracts was M.Cn<A.Cn $<M . A v<A . A v<M . C p<A . C p$. It was interesting to note that the aqueous extracts of individual plants were more suppressive to $A$. cepa root growth compared to their methanol extracts. Similarly, Bhattacharya and Haldar (2010) reported that the methanol extract of the plant tested gave less toxic effect in A. cepa root meristem cells compared to the aqueous extract. Apart from this, other investigations also revealed that methanol extracts of individual plants were more effective than their respective aqueous extracts (Opoku et al., 2000; Shoba and Thomas, 2001). This might be due to the possible presence of organic compounds, particularly the phytochemicals which were reported to be indirect contributors of plant growth and development, in methanol extract (Murphy et al., 2000; Salim et al., 2008). However, it might also be explained in the opposite way, whereby, the non-polar compounds present abundantly in methanol extracts might not have thoroughly dissolved in water; hence, expressed the effect of tap water rather than that of the extract itself. According to Fiskesjö (1985), incorrect results may be observed in A. cepa chromosome assay if the compounds are not fully dissolved.

Mitotic index was reported to be a good indicator to access the cytotoxic level, whereas chromosomal aberration was used to test mutagenicity of chemicals in cells (Akinboro et al., 2011a; Fiskesjö, 1985; Leme and MarinMorales, 2009). The microscopic evaluation showed that all plant extracts tested were not cytotoxic to onion root cells. However, a significantly lower MI in relation to 
Table 3.2: Antimutagenic effect of plant extracts against MMS (Treatment 2) in A. cepa root cells.

\begin{tabular}{|c|c|c|c|c|c|c|}
\hline Plant extract & $\begin{array}{l}\text { Conc. } \\
\text { (mg/kg) }\end{array}$ & $\begin{array}{l}\text { Total dividing } \\
\text { cells }\end{array}$ & $\begin{array}{c}\text { Total aberrant } \\
\text { cells }\end{array}$ & $\begin{array}{l}\% \text { CA in total } \\
\text { dividing cells }\end{array}$ & $\begin{array}{l}\text { \% reduction } \\
\text { of } \mathrm{CA}\end{array}$ & $\begin{array}{l}\text { Cell } \\
\text { death }\end{array}$ \\
\hline \multirow{6}{*}{$\begin{array}{l}\text { Aqueous extract of } \\
\text { C. nutans }\end{array}$} & $\mathrm{NC}$ & 404 & 13 & 3.22 & - & 0.30 \\
\hline & MMS & 61 & 11 & $18.03^{*}$ & - & 1.46 \\
\hline & 100 & 86 & 2 & 2.33 & 106.01 & 0.10 \\
\hline & 200 & 247 & 12 & 4.86 & 88.93 & 0.75 \\
\hline & 400 & 171 & 10 & 5.85 & 82.24 & 0.24 \\
\hline & 800 & 63 & 0 & 0 & 121.74 & 0.92 \\
\hline \multirow{6}{*}{$\begin{array}{l}\text { Methanol extract of } \\
\text { C. nutans }\end{array}$} & $\mathrm{NC}$ & 600 & 9 & 1.50 & - & 0.14 \\
\hline & MMS & 19 & 4 & $21.05^{*}$ & - & $16.2^{*}$ \\
\hline & 100 & 213 & 6 & 2.82 & 93.25 & 1.28 \\
\hline & 200 & 25 & 3 & $12.00^{*}$ & 46.29 & 1.34 \\
\hline & 400 & 14 & 2 & $14.29^{*}$ & 34.58 & $8.52^{*}$ \\
\hline & 800 & 60 & 5 & 8.33 & 65.06 & 7.20 \\
\hline \multirow{6}{*}{$\begin{array}{l}\text { Aqueous extract of } \\
\text { A. vasica }\end{array}$} & $\mathrm{NC}$ & 466 & 13 & 2.79 & - & 0.14 \\
\hline & MMS & 12 & 4 & $33.33^{*}$ & - & $10.62^{*}$ \\
\hline & 50 & 42 & 5 & $11.90^{*}$ & 70.17 & 3.72 \\
\hline & 100 & 19 & 1 & 5.26 & 91.91 & 3.82 \\
\hline & 200 & 20 & 1 & 5.00 & 92.76 & 1.36 \\
\hline & 400 & 57 & 3 & 5.26 & 91.91 & 0.68 \\
\hline \multirow{6}{*}{$\begin{array}{c}\text { Methanol extract of } \\
\text { A. vasica }\end{array}$} & $\mathrm{NC}$ & 522 & 11 & 2.11 & - & 0.14 \\
\hline & MMS & 7 & 3 & $42.86^{*}$ & - & 4.62 \\
\hline & 50 & 31 & 4 & $12.90^{*}$ & 73.52 & 4.30 \\
\hline & 100 & 22 & 1 & 4.55 & 94.01 & 1.56 \\
\hline & 200 & 20 & 1 & 5.00 & 92.91 & 0.88 \\
\hline & 400 & 92 & 6 & 6.52 & 89.18 & 1.14 \\
\hline \multirow{6}{*}{$\begin{array}{l}\text { Aqueous extract of } \\
\text { C. papaya }\end{array}$} & $\mathrm{NC}$ & 433 & 8 & 1.85 & - & 0.78 \\
\hline & MMS & 41 & 7 & $17.07^{*}$ & - & $7.82^{*}$ \\
\hline & 50 & 61 & 4 & 6.56 & 69.05 & 2.02 \\
\hline & 100 & 65 & 4 & 6.15 & 71.75 & 5.46 \\
\hline & 200 & 107 & 3 & 2.80 & 93.76 & 4.18 \\
\hline & 400 & 68 & 1 & 1.47 & 102.50 & 0.38 \\
\hline \multirow{6}{*}{$\begin{array}{l}\text { Methanol extract of } \\
\text { C. papaya }\end{array}$} & $\mathrm{NC}$ & 451 & 20 & 4.43 & - & 0.02 \\
\hline & MMS & 29 & 5 & $17.24^{*}$ & - & $4.40^{*}$ \\
\hline & 50 & 38 & 3 & 7.89 & 72.99 & 0.68 \\
\hline & 100 & 33 & 2 & 6.06 & 87.28 & 0.58 \\
\hline & 200 & 47 & 4 & 8.51 & 68.15 & 2.10 \\
\hline & 400 & 69 & 4 & 5.80 & 89.31 & 1.42 \\
\hline
\end{tabular}

Conc.: concentration * indicates significant difference from negative control (NC), $\mathrm{p} \leq 0.05$.

control was recorded for A. vasica extract at $50 \mathrm{mg} / \mathrm{kg}$. Such lower MI indicates cytotoxicity and causes negative changes to the cell's system, thus affecting the synthesis of DNA or formation of daughter nuclei (Akinboro et al., 2011). According to Fiskesjö, 1985, the root growth inhibition resembles total damage to cells system, caused by the chemical action. Furthermore, the statistically significant CAs observed at the tested concentrations of 200 and $400 \mathrm{mg} / \mathrm{kg}$ of methanol extract of C. papaya shows its potential mutagenic activity at higher concentrations. Statistically higher CA at $400 \mathrm{mg} / \mathrm{kg}$ of aqueous extract of C. nutans explains its potential moderate mutagenicity in plant cells, though $800 \mathrm{mg} / \mathrm{kg}$ of the extract was not statistically differ than negative control.

Mutagens are known to prompt gene mutations or alteration in cells and thus, may affect somatic and germinal cells. Any mutations at the level of germinal cells might be inherited by next generations. Sadly, the degree of exposure of mankind to mutagens is still high (Varanda et al., 1999). Therefore, in line to that, the potency of the plant extracts to repair the damages induced in MMS-pre-treated (Treatment 1) A. cepa root cells and to effectively suppress the mutagenic activity when co-administered (Treatment 2) was investigated. The potential anti-cytotoxic and antimutagenic activity of methanol extract of $C$. nutans and aqueous extract of both A. vasica and C. papaya against MMS in A. cepa root cells was noted, especially in treatment 1 . Aqueous extract of $C$. nuatns at all tested concentrations were found to promote the cell proliferation, however, the $800 \mathrm{mg} / \mathrm{kg}$ of aqueous extract of $C$. nutans was noted to cause a vigorous cell division (significantly higher than negative control) in $A$. cepa root cells which were pre-treated with MMS. Vigorous proliferation of cells is considered dangerous to organisms, since this situation might results in malignant or tumor cells formation (Leme and Marin-Morales, 2009). On the contrary, methanol extract of $C$. nutans was found to be more cytotoxic as the concentration increased. At the same time, the plant extract was able reduce the percentage CA induced by MMS in A. cepa root cells. The cytotoxic and antimutagenic activity may be due to the likelihood of principle active compounds such as flavonoid glycosides, cerebrosides, monoacylmonogalactosylglycerol, botulin and lupeol (triterpenoids), vitexin and etc. present in the extract of $C$. nutans (Dampawan et al., 1977; Hasegawa et al., 2008; Sakdarat et al., 2009; Tuntiwachwuttikul et al., 2004). Phytochemicals such as phenolic compounds, flavonoids and triterpenoids were well known for their anticarcinogenic and antioxidant activity (Akinboro et al., 2011a; Bishayee et al., 2011; Halliwell et al., 1995). It has been earlier reported that some bioactive compounds that are anticarcinogenic in nature may act in a way that it could be cytotoxic in cells through mitotic suppression (Akinboroet al., 2011a). This suggestion was in line with the results obtained at 200, 400 , and $800 \mathrm{mg} / \mathrm{kg}$ of methanol extract of C. nutans, whereby at higher concentrations and with the presence of mutagen, the active compounds might have suppressed mitosis in onion cells. Extracts of A. vasica and C. papaya in treatment 1 gave almost similar, but poor results when 
compared to the extracts of C. nutans. The potential of extracts of $A$. vasica at $50 \mathrm{mg} / \mathrm{kg}$ to suppress the MMSinduced cytotoxicity may be due to the presence of alkaloids, triterpenes, and flavonoids as reported in previous reports (Claeson et al., 2000; Huq et al., 1967).

A parallel pattern was observed in the treatment 2, where methanol extracts were less effective than aqueous extracts. Yet, in this treatment, the plant extracts were noted to be poor mutagen inhibitors compared to earlier treatment. According to Hemminki (1993), some carcinogens or mutagens could form strong DNA-adducts, where the mutagens binds covalently to DNA and induces error prone cell divisions. This might explains to the modest activity of the plant extracts to inhibit the mutagenicity of MMS since the compounds in the extracts might not be strong enough to compete with MMS to react with $A$. cepa root cell components. Similar results were observed by Varanda and co-workers (1999), whereby the sample they used was unable to suppress the activity of certain tested mutagens. The results obtained for both aqueous and methanol extracts of C. papaya against MMS-induced cytotoxicity and mutagenicity explains the moderate antimutagenicity of the plant extract against MMS. In line to this, earlier reports regarding moderate antimutagenic and antitumor activity of $C$. papaya extracts were reported (Akinboro and Bakare, 2007; Mazzio and Soliman, 2009).

The occurrence of cells in death phase was found in all treated groups including negative control, though the values were very low than MMS-induced cell deaths. Programmed cell death is a natural process which could occur during normal cell development. Despite that, it might also be prompted by external compounds which are toxic to parental cells (Wang et al., 1996). These suggestions are thus in line with the results obtained from negative control, plant extracts, and MMS. Among all the treatments, MMS-represent cell death was noted to be higher than others. The plant extracts were observed to repair the morphological impairments caused by MMS even though the values at certain concentrations of plant extracts were significantly higher than negative control. Apart from that, the cell death recorded for tap water and extracts (prepared using tap water) might also be reasoned by the possible presence of chemicals such as heavy metals in tap water as it has been proven by many studies (Akinboro et al., 2011; Farghaly, 2003; Maharia et al., 2013). The observation of cell death in the form of shrinkage in nuclear volume, nuclear fragmentation, bridge between two interphasic nuclei, buddings, and sticky nucleus were also noted in various investigations (Hoshina and Marine-Morales, 2009; Leme and MarinMorales, 2009; Wang et al., 1996). Therefore, apart from MI and CA, cell death or nuclear abnormalities were also considered a good indicator of mutagenicity as obtained in the test groups.

\section{CONCLUSION}

The Allium cepa assay was an applicable test system to access information on toxicity of various environmental toxins and mutagens. Many cancer drugs available in markets and used in chemotherapies were cytotoxic to cells which explain their suppressiveness against cancer cells. Unfortunately, their cytotoxic capability might also affect the neighbouring normal cells which were obvious through many side effects encountered by patients undergoing chemotherapy such as nausea, fatigue, hair loss, and etc. Concerning this issue, it is very crucial to investigate potential antimutagens with less cytotoxic activity to normal cells. All in all, the results showed that methanol extract of $C$. nutans and aqueous extracts of $A$. vasica and $C$. papaya have the potency to suppress the mutagen and thus could be a promising antimutagen. The order of plant extracts with increasing antimutagenic activity was $C$. papaya $<A$. vasica $<C$. nutans. Further investigations are in progress to validate the antimutagenic property of $C$. nutans using in vivo animal assay.

\section{ACKNOWLEDGEMENT}

A deepest gratitude to University Science Malaysia (USM) for their material and financial support through USM Fellowship and a USM short-term grant (grant no.: 304/PBIOLOGY/6311041) to undertake this study.

\section{REFERENCES}

Akinboro, A., \&Bakare, A. A. (2007).Cytotoxic and genotoxic effects of

aqueous extracts of five medicinal plants on Allium cepa Linn.Journal of Ethnopharmacology, 112(3), 470-475. [DOI]

Akinboro, A., Mohamed, K. B., Asmawi, M. Z., \&Sofiman, O. A. (2011) Mutagenic and antimutagenic potentials of fruit juices of five medicinal plants in Allium cepa L.: Possible influence of DPPH free radical scavengers. African Journal of Biotechnology, 10(51), 10520-10529. [DOI]

Akinboro, A., Mohammed, K., Selestin, R., \&Muniandy, V. R. (2011).Genotoxicity Assessment of Water Samples from the Sungai Dua River in Pulau Pinang, Malaysia, Using the Allium cepa Test. Tropical Life Sciences Research, 22(2), 23-35.

Amin, A. H., \& Mehta, D. R. (1959). A Bronchodilator Alkaloid (Vasicinone) from AdhatodavasicaNees. Nature, 184(4695), 1317-1317. [DOI]

Ayyanar, M., \&Ignacimuthu, S. (2008). Medicinal uses and pharmacological Actions of five commonly used Indian Medicinal plants: A minireview. Iranian J. Pharm. Therapeut, 7, 107-114.

Balasubramanian, A., Ramalingam, K., Krishanan, S., \& Christina, A. J. M. (2005). Anti-inflammatory activity of Morusindica Linn.Bioline International, 4(1).

Bhattacharya, S., \&Haldar, P. K. (2010).Evaluation of in vitro cytotoxic effect of Trichosanthesdioica root.Pharmacognosy research, 2(6), 355. [DOI]

Bishayee, A., Ahmed, S., Brankov, N., \&Perloff, M. (2011). Triterpenoids as potential agents for the chemoprevention and therapy of breast cancer.Frontiers in bioscience: a journal and virtual library, 16, 980.

Chakraborty, A., \&Brantner, A. H. (2001). Study of alkaloids from AdhatodavasicaNees on their antiinflammatory activity. Phytotherapy Research, 15(6), 532-534. [DOI]

Claeson, U. P., Malmfors, T., Wikman, G., \& Bruhn, J. G. (2000).Adhatodavasica: a critical review of ethnopharmacological and toxicological data. Journal of Ethnopharmacology, 72, 1-20. [DOI]

Dampawan, P., Huntrakul, C., Reutrakul, V., Raston, C. L., \& White, A. H. (1977). Constituents of Clinacanthusnutans and the crystal structure of LUP-20 (29)-ENE-3-ONE. Journal of Science Society of Thailand, 3, 1426. [DOI]

Dhuley, J. N. (1999). Antitussive effect of Adhatodavasica extract on mechanical or chemical stimulation-induced coughing in animals.Journal of Ethnopharmacology, 67(3), 361-365. [DOI]

Farghaly, O. A. (2003). Direct and simultaneous voltammetric analysis of heavy metals in tap water samples at Assiut city: an approach to improve the analysis time for nickel and cobalt determination at mercury film electrode. Microchemical Journal, 75(2), 119-131. [DOI]

Fiskesjö, G. (1985). The Allium test as a standard in environmental monitoring.Hereditas, 102(1), 99-112. [DOI]

Halliwell, B., Aeschbach, R., Löliger, J., \&Aruoma, O. I. (1995).The characterization of antioxidants.Food and Chemical Toxicology, 33(7), 601-617. [DOI]

Halliwell, B., \&Gutteridge, J. M. (1984).Oxygen toxicity, oxygen radicals, transition metals and disease.Biochem J. , 219(1), 1-14.

Hasegawa, T., Tanaka, A., Hosoda, A., Takano, F., \&Ohta, T. (2008).Antioxidant C-glycosyl flavones from the leaves of Sasakurilensis var. gigantea.Phytochemistry, 69(6), 1419-1424. [DOI]

Hemminki, K. (1993). DNA adducts, mutations and cancer. Carcinogenesis, 14(10), 2007-2012. [DOI]

Hirose, M., Takesada, Y., Tanaka, H., Tamano, S., Kato, T., \&Shirai, T. (1998). Carcinogenicity of antioxidants BHA, caffeic acid, sesamol, 4methoxyphenol and catechol at low doses, either alone or in combina- 
tion, and modulation of their effects in a rat medium-term multi-organ carcinogenesis model. Carcinogenesis, 19(1), 207-212. [DOI]

Hoshina, M. M. \& Marin-Morales, M. A. (2009). Micronucleus and chromosome aberrations induced in onion (Allium cepa) by a petroleum refinery effluent and by river water that receives this effluent. Ecotoxicology and Environmental Safety, 72(8), 2090-2095. [DOI]

Huq, M., Ikram, M., \&Warsi, S. (1967).Chemical composition of Adhatodavasica Linn-II.Pak. J. Sci. Ind. Res, 10, 224-225.

Jayaraj, P. (2010). Regulation of traditional and complementary medicinal products in Malaysia.Int J Green Pharm 4(1), 1014.http://dx.doi.org/10.4103/0973-8258.62158

Jemal, A., Center, M. M., DeSantis, C., \& Ward, E. M. (2010).Global Patterns of Cancer Incidence and Mortality Rates and Trends.Cancer Epidemiology Biomarkers \& Prevention, 19(8), 1893-1907. [DOI]

Kahl, R. (1984). Synthetic antioxidants: Biochemical actions and interference with radiation, toxic compounds, chemical mutagens and chemical carcinogens. Toxicology, 33, 185-228. [DOI]

Kaptchuk, T. J. (1947). The web that have no weaver: Undestandingchinese medicine. 2nd ed.

Krishnaraju, A. V., Rao, T. V. N., Sundararaju, D., Vanisree, M., Tsay, H.-S., \&Subbaraju, G. V. (2006). Biological Screening of Medicinal Plants Collected from Eastern Ghats of India Using Artemiasalina (Brine Shrimp Test). International Journal of Applied Science and Engineering, 4(2), 115-125.

Leme, D. M., \& Marin-Morales, M. A. (2009). Allium cepa test in environmental monitoring: A review on its application. Mutation Research/Reviews in Mutation Research, 682(1), 71-81. [DOI]

Levan, A. (1938). The effect of colchicine on root mitoses in allium.Hereditas, 24(4), 471-486.http://dx.doi.org/10.1111/j.16015223.1938.tb03221.x

Luximon-Ramma, A., Bahorun, T., \& Crozier, A. (2003).Antioxidant actions and phenolic and vitamin $C$ contents of common Mauritian exotic fruits.Journal of the Science of Food and Agriculture, 83(5), 496-502. [DOI]

Maharia, R. S., Dutta, R. K., Acharya, R., \& Reddy, A. V. R. (2013). Heavy metal bioaccumulation in selected medicinal plants collected from Khetri copper mines and comparison with those collected from fertile soil in Haridwar, India. Journal of Environmental Science and Health, Part B, 45(2), 174-181. [DOI]

Mazzio, E. A., \&Soliman, K. F. A. (2009).In vitro screening for the tumoricidal properties of international medicinal herbs.Phytotherapy Research, 23(3), 385-398. [DOI]

Murphy, A., Peer, W. A., \&Taiz, L. (2000).Regulation of auxin transport by aminopeptidase and endogenous flavonoids.Planta, 211(3), 315-324. [DOI]

Nair, R., \&Chanda, S. V. (2007). Antibacterial activities of some medicinal plants of the western region of India.Turk J Biol., 31, 231-236

Okoko, T., \& Ere, D. (2012).Reduction of hydrogen peroxide-induced erythrocyte damage by Carica papaya leaf extract.Asian Pacific Journal of Tropical Biomedicine, 2(6), 449-453. [DOI]

Padmaja, M., Sravanthi, M., \&Hemalatha, K. P. J. (2011).Evaluation of Antioxidant Activity of Two Indian Medicinal Plants.Journal of Phytology, 3(3), 86-91.

Palasuwan, A., Soogarun, S., Lertlum, T., Paweena, Pradniwat, \&Wiwanitkit, V. (2005).Inhibition of Heinz Body Induction in an inVitro Model and Total Antioxidant Activity of Medicinal Thai Plants.Cancer Prevention, 6.
Patel, P. M, Jivani, N., Malaviya, S, Gohil, T \& Bhalodia, Y. (2012) Cataract: A major secondary diabetic complication. International Current Pharmaceutical Journal, 1(7), 180-185. [DOI]

Razak, M. F. A., Aidoo, K. E., \&Candlish, A. G. G. (2007).Mutagenic and cytotoxic properties of three herbal plants from Southeast Asia.Tropical Biomedicine, 24(2), 49-59.

Runnie, I., Salleh, M. N., Mohamed, S., Head, R. J., \&Abeywardena, M. Y. (2004). Vasorelaxation induced by common edible tropical plant extracts in isolated rat aorta and mesenteric vascular bed. Journal of Ethnopharmacology, 92(2), 311-316. [DOI]

Safer, A. M., \& Al-Nughamish, A. J. (1999). Hepatotoxicity induced by the anti-oxidant food additive, butylatedhydroxytoluene BHT, in rats. An electron microscopical study.Histology and histopathology, 14(2).

Sakdarat, S., Shuyprom, A., Pientong, C., Ekalaksananan, T., \&Thongchai, S. (2009).Bioactive constituents from the leaves of Clinacanthusnutans Lindau. Bioorganic \& medicinal chemistry, 17(5), 1857-1860. [DOI]

Salim, A. A., Chin, Y.-W., \&Kinghorn, A. D. (2008).Drug discovery from plants.Bioactive Molecules and Medicinal Plants, 1-24. [DOI]

Sharmeen, R., Hossain, M. N., Rahman, M. M., Foysal, M. J., \&Miah, M. F. (2012). In-vitro antibacterial activity of herbal aqueous extract against multi-drug resistant Klebsiella sp. isolated from human clinical samples. International Current Pharmaceutical Journal, 1(6), 133-137. [DOI]

Shoba, F. G., \& Thomas, M. (2001). Study of antidiarrhoeal activity of four medicinal plants in castor-oil induced diarrhoea. Journal of Ethnopharmacology, 76(1), 73-76. [DOI]

Starley, I. F., Mohammed, P., Schneider, G., \&Bickler, S. W. (1999). The treatment of paediatric burns using topical papaya. Burns, 25(7), 636639. [DOI]

Stepek, G., Behnke, J. M., Buttle, D. J., \&Duce, I. R. (2004).Natural plan cysteine proteinases as anthelmintics?Trends in Parasitology, 20(7) 322-327. [DOI]

Tuntiwachwuttikul, P., Pootaeng-on, Y., Phansa, P., \& Taylor, W. C. (2004).Cerebrosides and a monoacylmonogalactosylglycerol from Clinacanthusnutans.Chemical and pharmaceutical bulletin, 52(1), $27-$ 32. [DOI]

Valerio, L. G., \& Gonzales, G. F. (2005). Toxicological Aspects of the South American Herbs Cat's Claw (Uncariatomentosa) and Maca (Lepidiummeyenii): A Critical Synopsis. Toxicological Reviews, 24(1), 11-35. [DOI]

Varanda, E. A., Monti, R., \& Tavares, D. C. (1999). Inhibitory effect of propolis and bee venom on the mutagenicity of some direct- and indirect-acting mutagens.Teratogenesis, carcinogenesis, and mutagenesis, 19(6), 403-413. [DOI]

Vicentini, V. E. P., Camparoto, M. L., Teixeira, R. O., \&Mantovani, M. S (2001). In: Averrhoacarambola L., Syzygiumcumini (L.) SkeelsanndCissussicoydes L.: Medicinal herbal tea effects on vegetal and animal test systems. ActaScientiarum(23), 593-598.

Wang, H., Li, J., Bostock, R. M., \& Gilchrist, D. G. (1996). Apoptosis: functional paradigm for programmed plant cell death induced by a host-selective phytotoxin and invoked during development. The Plant Cell Online, 8(3), 375-391. [DOI]

Wanyoike, G. N., Chhabra, S. C., Lang'at-Thoruwa, C. C., \& Omar, S. A. (2004). Brine shrimp toxicity and antiplasmodial activity of five Kenyan medicinal plants.Journal of Ethnopharmacology, 90(1), 129-133. [DOI]

World Health Organization (WHO): [LINK] 